\title{
Physicochemical characteristics and physiological activities of mixture extracts from Liriope platyphylla, Schizandra chinensis, and Panax ginseng C.A. Meyer
}

\author{
Yul-Ri Gu, Joo-Heon Hong* \\ Department of Food Science and Technology, Catholic University of Daegu, Gyeongsan 38430, Korea
}

\section{맥문동, 오미자 및 인삼 혼합추출물의 이화학적 특성 및 생리활성}

\author{
구율리 · 홍주헌* \\ 대구가톨릭대학교 식품공학전공
}

\begin{abstract}
This study was conducted to examine the antioxidant activities and physiological activities of mixture extracts (Liriope platyphylla, Schizandra chinensis and Panax ginseng C.A. Meyer) with different extraction mixing ratios (MEC, 2:1:1; ME1, 1:2:1; ME2, 1:1:2; ME3, 1.34:1.33:1.33). The yield of extracts ranged from 25.33 to $33.87 \%$. The total polyphenol and total flavonoid contents of ME1 extracts were $1.01 \mathrm{~g} / 100 \mathrm{~g}, 0.07 \mathrm{~g} / 100 \mathrm{~g}$, respectively. The total sugar contents of MEC extract was $22.83 \mathrm{~g} / 100 \mathrm{~g}$, respectively. The DPPH and ABTS radical scavenging activities of ME1 extracts at $1,000 \mu \mathrm{g} / \mathrm{mL}$ were $26.79 \%$ and $21.08 \%$. The superoxide radical scavenging and ferric-reducing antioxidant power of ME1 extracts at $1,000 \mu \mathrm{g} / \mathrm{mL}$ were $67.83 \%$ and $295.47 \mu \mathrm{M}$, respectively. The functionalities of extracts were investigated with $\mathrm{L}-132$ and RAW264.7 cell lines. The extracts on different mixing ratios did not show the toxicity on L-132 and RAW264.7 cell line in 100-2,500 $\mu \mathrm{g} / \mathrm{mL}$. The ME1 extract of 1,000 $\mu \mathrm{g} / \mathrm{mL}$ performed better than other extracts protective effects against oxidative stess in $\mathrm{L}-132$ cells $(81.22 \%)$ and the ME2 extract at $1,000 \mu \mathrm{g} / \mathrm{mL}$ decreased nitric oxide production by $7.48 \mu \mathrm{M}$ which was more potent than other extracts. There results suggest that the ME1 extracts may be a useful functional food material in the food industry.
\end{abstract}

Key words : Liriope platyphylla, Schizandra chinensis, Panax ginseng C.A. Meyer, physicochemical characteristics, antioxidant activities

\section{서 론}

인체는 산화적 스트레스로부터 자신을 보호하기 위해 활성산소종으로부터 숙주를 보호하는 방어체계를 가지고 있으나, 산화적 스트레스의 강도가 클 경우 생체 내 산화작 용을 효율적으로 예방하기 위해 지속적인 항산화 물질 섭취 가 필요하다(1). 항산화제로 알려져 있는 2 차 대사산물인

*Corresponding author. E-mail : jhhong@cu.ac.kr

Phone : 82-53-850-3218, Fax : 82-53-850-3218

Received 31 March 2017; Revised 1 May 2017; Accepted 16 May 2017.

Copyright (c) The Korean Society of Food Preservation. All rights reserved.
페놀화합물은 채소류, 과일 및 한약재 등과 같은 식물 소재 에 다량 함유되어 있어 가공식품의 주원료 또는 부재료로 건강 기능 증진을 위한 소재로 이용되고 있으며, 식물 소재 에 대한 항산화 활성 연구가 수행되어져 왔다 $(2,3)$. 항산화 활성을 가지는 원료는 염증성 질환에도 효과를 보이는데, 염증반응은 여러 가지 형태의 감염이나 생체 내 대사산물 중의 자극성 물질에 대한 생체 방어기작이다. Nitric oxide(NO)는 염증반응의 대표적인 매개체로 혈압조절 및 신경전달 작용 등의 역할을 하지만, 체내에 필요 이상으로 생성되면 세포 사멸 및 면역 체계 이상을 나타낸다 $(4,5)$. 이러한 염증반응에서 방어적 역할을 담당하는 대식세포는 혈액 단핵세포로부터 분화한 조직 세포이며, lipopolysaccharide (LPS)는 대식세포 표면의 toll-like receptor(TLR)를 자극하 
여 신호전달경로의 활성화를 유도하고, 유도된 신호전달경 로는 여러 가지 염증성 매개인자들의 발현을 유도한다(6).

현대인들의 항산화와 염증 및 면역에 관한 관심은 현재 생활수준의 급속한 향상과 함께 많은 성인병이 보편화된 것과 여유로운 생활과 건강한 삶을 추구하는 것에 기인한 다. 이에 따라 질환예방의 목적으로 최근 생리활성을 가지 는 식품에 대한 연구가 활발히 진행 중이며, 한국인의 취향 에 맞는 건강기능식품들이 많이 개발되고 있다 $(7,8)$. 그 중 생맥산(生脈散)은 맥문동(Liriope platyphylla), 오미자(Schizandra chinensis) 및 인삼(Panax ginseng C.A. Meyer)을 추출 및 혼합하여 만든 전통한방음료로서 원기부족, 식욕부진, 여 름철 더위에 땀을 많이 흘려 기운이 없거나 마른기침을 하고 식은땀을 흘릴 때 예로부터 음용하여 왔으며, 전신의 생리기능을 촉진하여 심장기능 회복 및 면역증강에도 응용 되고 있다(9).

생맥산 원료 중 맥문동(Liriope platyphylla)은 백합과에 속하는 다년생 초본 약용식물로 우리나라, 중국, 일본 등에 분포하며, 주로 덩이뿌리를 한약재로 폐기능 및 체력 향상 을 돕는 약재로서 기침, 가래, 해열 등 약리작용을 한다 $(10,11)$. 맥문동의 다양한 생리활성물질에 관한 연구로는 ophiogonine-A 등 7종류의 saponin과 flavonoid sterol, isoflavonoid, stigmasterol, $\beta$-sitosterol, polysaccharides 및 oligosaccharides 등이 있으며, steroid saponin의 항암효과와 그 외 항염증, 미생물 억제, 혈당강하, 당뇨예방, 기억력 증진 등의 기능이 있다고 알려져 있다(12,13). 오미자는 오 미자나무과(Schisandraceae)에 속하는 오미자나무(Schizandra chinensis Baillon)의 열매로서 신경쇠약, 두통, 간염 등의 치료 및 진해, 거담 효과를 나타내는 한약재이다. 오미자의 약리기능은 항산화작용, 면역력증강, 항균효과 및 위암세 포 사멸 등 다양한 연구가 수행되었다 $(14,15)$. 오미자의 주 성분은 lignan 화합물이고, palmitic acid와 stearic acid 등의 지방산, anthocyanin 등의 색소 및 유기산 등을 함유하고 있다(16). 인삼은 오갈피나무과(Araliaceae)의 인삼속에 속 하는 다년생 초본 약용식물로 사용된 역사가 깊은 우리나라 의 대표적인 한약재이다(17). 주요한 생리활성 물질로는 ginsenosides, polyacetylenes, 페놀성 화합물 $(18,19)$ 과 면역 활성, 항종양활성 혈당강하효능 등을 가지는 다당체 성분 들이 있으며(20), 항피로작용, 면역력 증진, 항암, 항산화 효과 및 몸속의 지방 대사를 촉진시키는 기능성 식품으로 알려져 있다 $(21,22)$. 이처럼 맥문동, 오미자 및 인삼 혼합추 출물인 생맥산은 많은 약리작용과 효능을 가지고 있음에도 불구하고, 생맥산 원료인 맥문동, 오미자 및 인삼 각각에 대한 연구는 활발히 진행되고 있지만 생맥산 자체에 대한 연구는 미흡한 실정이다.

따라서 본 연구에서는 맥문동, 오미자 및 인삼의 혼합비 율에 따른 추출물의 이화학적 특성과 항산화 활성 및 $\mathrm{NO}$ 생성 억제능을 비교분석하여 기능성이 증진된 맥문동, 오
미자 및 인삼 혼합비율을 설정하고, 이를 이용한 기능성 식품소재 개발을 위한 기초자료를 제공하고자 한다.

\section{재료 및 방법}

\section{실험재료}

본 실험에 사용된 맥문동은 충청남도 청양군, 건오미자 는 경상북도 문경시 및 인삼은 경상북도 영주시에서 재배되 어 건조된 것을 2016년 12 월 경상북도 영천시 소재 농업회 사법인 두손애약초에서 구입하여 사용하였으며, 구입한 재 료는 냉장 보관하였다.

\section{추출물의 제조}

맥문동은 열풍건조기(OF-22, Jeiotech, Daejeon, Korea)에 서 $50^{\circ} \mathrm{C}, 24$ 시간 건조하여 수분함량이 $10 \%$ 가 되도록 하였 다. 그 후, 맥문동 및 인삼을 건식분쇄기(NSG-1002SS, Hanil, Sejong, Korea)로 각각 분쇄하여 $60 \mathrm{mesh}$ 이하의 분말 과 건오미자 원시료를 Table 1 과 같이 비율별로 혼합한 시료 $30 \mathrm{~g}$ 에 증류수 $300 \mathrm{~mL}$ 를 첨가하였다. 환류냉각추출기 (CA-1112, Eyela Co., Tokyo, Japan)를 이용하여 $100^{\circ} \mathrm{C}$ 에서 4시간 추출하였으며, 각각의 추출물은 여과지(Whatman No. 2)를 이용하여 불순물을 제거하였다. 여과된 용액은 감압농축기(Model N-1N, Eyela Co., Tokyo, Japan)를 이용 하여 농축한 후, 동결건조기(Free Zone 2.5, Labconco Co., Kansas, MO, USA)로 건조하여 $-70^{\circ} \mathrm{C}$ 이하의 암소에 보관하 면서 분석용 시료로 사용하였다.

Table 1. Mixture ratios of Liriope platyphylla, Schizandra chinensis, and Panax ginseng C.A. Meyer

\begin{tabular}{cccc}
\hline Samples $^{1)}$ & Liriope platyphylla & Schizandra chinensis & $\begin{array}{c}\text { Panax ginseng C.A. } \\
\text { Meyer }\end{array}$ \\
\hline MEC & 2 & 1 & 1 \\
ME1 & 1 & 2 & 1 \\
ME2 & 1 & 1 & 2 \\
ME3 & 1.34 & 1.33 & 1.33 \\
\hline
\end{tabular}

${ }^{1)}$ MEC, Mixed extract of control (Liriope platyphylla : Schizandra chinensis : Panax ginseng C.A. Meyer $=2: 1: 1$ ); ME1, Mixed extract 1 (Liriope platyphylla : Schizandra chinensis : Panax ginseng C.A. Meyer $=1: 2: 1)$; ME2, Mixed extract 2 (Liriope platyphylla : Schizandra chinensis: Panax ginseng C.A. Meyer $=1$ : 1 : 2); ME3, Mixed extract 3 (Liriope platyphylla : Schizandra chinensis : Panax ginseng C.A. Meyer $=1.34: 1.33: 1.33$ ).

\section{추출수율}

맥문동, 오미자 및 인삼 혼합추출물의 수율은 동결건조 (Free Zone 2.5, Labconco Co.)한 다음 건물 중량을 구하였고 시료 제조에 사용한 원료 건물량에 대한 백분율로 나타내었 다. 
총 폴리페놀, 총 플라보노이드 및 총 당 함량

총 폴리페놀 함량은 Folin-Denis법(23)에 따라 측정하였 다. 시료 $1 \mathrm{~mL}$ 와 $1 \mathrm{~N}$ Folin Ciocalteu reagent $1 \mathrm{~mL}$ 를 혼합한 다음 $20 \% \mathrm{Na}_{2} \mathrm{CO}_{3} 1 \mathrm{~mL}$ 를 첨가하여 실온의 암소에서 30 분 간 반응시킨 후 분광광도계(Ultrospec 2100pro, Biochrom Ltd., Cambridge, UK)를 이용하여 $725 \mathrm{~nm}$ 에서 흡광도를 측정하였다. 총 폴리페놀 함량은 tannic acid(Sigma-Aldrich Co., St. Louis, MO, USA)로 표준곡선을 작성하여 계산하였다. 총 플라보노이드 함량은 Jia 등(24)의 방법을 응용하여 측정하였다. 시료 $1 \mathrm{~mL}$ 와 $5 \% \mathrm{NaNO}_{2} 150 \mu \mathrm{L}$ 를 실온에서 6분간 혼합 및 반응시킨 후 $10 \% \mathrm{AlCl}_{3} 300 \mu \mathrm{L}$ 와 혼합하여 다시 실온에서 5 분간 반응 시킨 다음 $1 \mathrm{~N} \mathrm{NaOH} 1 \mathrm{~mL}$ 와 혼합한 다음 분광광도계(Ultrospec 2100pro, Biochrom Ltd.) 를 이용하여 $510 \mathrm{~nm}$ 에서 흡광도를 측정하였다. 총 플라보 노이드함량은 rutin(Sigma-Aldrich Co.)으로 표준곡선을 작 성하여 계산하였다.

총 당 함량은 phenol-sulfuric acid 방법(25)을 응용하여 측정하였다. 시료 $1 \mathrm{~mL}$ 와 $5 \%$ phenol $1 \mathrm{~mL}$ 및 진한 $\mathrm{H}_{2} \mathrm{SO}_{4}$ $5 \mathrm{~mL}$ 를 혼합하여 20 분간 반응 시킨 후, 분광광도계 (Ultrospec 2100pro, Biochrom Ltd.)를 이용하여 $470 \mathrm{~nm}$ 에서 흡광도를 측정하였다.

\section{Radical 소거활성 측정}

1,1-diphenyl-2-picryl hydrazyl(DPPH) radical 소거활성 (26)은 DPPH 용액을 DPPH $12 \mathrm{mg}$ 을 99.9\% ethanol 100 $\mathrm{mL}$ 에 용해한 후, 증류수 $100 \mathrm{~mL}$ 첨가하여 흡광도 $517 \mathrm{~nm}$ 에 서 약 1.5 로 조정 및 제조하여 실험하였다. 시료 $0.5 \mathrm{~mL}$ 와 $\mathrm{DPPH}$ reagent $5 \mathrm{~mL}$ 를 혼합하여 실온에서 15 분간 반응시킨 후, 분광광도계(Ultrospec 2100pro, Biochrom Ltd.)로 흡광 도를 측정하고 계산하였다.

2,2'-azino-bis(3-ethylbenzothiazoline-6-sulfonic acid)(ABTS) radical 소거활성은 $7.4 \mathrm{mM} \mathrm{ABTS(Sigma-Aldrich}$ Co.)와 $2.45 \mathrm{mM}$ potassium persulfate를 최종 농도로 혼합하여 실온의 암소에서 24 시간 동안 방치하여 $\mathrm{ABTS}^{+}$을 형성시킨 후 흡광도 $732 \mathrm{~nm}$ 에서 $0.70 \pm 0.03$ 이 되도록 phosphate buffer saline(PBS, $\mathrm{pH}$ 7.4)으로 희석하여 실험하였다(27). 희석된 용 액 $180 \mu \mathrm{L}$ 에 시료 $20 \mu \mathrm{L}$ 를 혼합하여 1 분간 반응시킨 다음 분광광도계(Ultraspec 2100pro, Biochrom Ltd.)를 이용하여 흡 광도 $732 \mathrm{~nm}$ 에서 측정하였다. ABTS radical 소거활성은 추출 물의 첨가 전과 후의 차이를 계산하였다.

Superoxide radical 소거활성은 Nishikimi 등(28)의 방법에 따라 측정하였다. 시료 $500 \mu \mathrm{L}$ 와 $0.1 \mathrm{M}$ Tris- $\mathrm{HCl}$ 완충용액 (pH 8.5) $100 \mu \mathrm{L}, 100 \mu \mathrm{M}$ phenazine methosulfate(PMS, Sigma-Aldrich Co.) $200 \mu \mathrm{L}$ 를 혼합시킨 후, $500 \mu \mathrm{L}$ nitro blue tetrazolium(NBT, Sigma-Aldrich Co.) $200 \mu \mathrm{L}$ 및 500 $\mu \mathrm{M}$ ß-nicotinamide adenine dinucleotide(NADH, SigmaAldrich Co.) $400 \mu \mathrm{L}$ 를 첨가하여 실온에서 10분간 반응시킨
다음 분광광도계(Ultraspec 2100pro, Biochrom Ltd.)를 이용 하여 흡광도 $560 \mathrm{~nm}$ 에서 측정하였다. Superoxide radical 소거활성은 추출물의 첨가 전과 후의 차이를 계산하였다.

$\mathrm{DPPH}, \mathrm{ABTS}$, Superoxide radical 소거활성은 양성대조군 으로서 ascorbic acid를 사용하여 활성을 비교하였다.

Radical 소거활성 $(\%)=\left(1-\frac{\mathrm{S}}{\mathrm{C}}\right) \times 100$

$\mathrm{S}=$ absorbance of sample at $517 \mathrm{~nm}$

$\mathrm{C}=$ absorbance of control at $517 \mathrm{~nm}$

Ferric reducing antioxidant power(FRAP) 측정

FRAP는 Benzie와 Strain의 방법(29)에 따라 측정하였다. FRAP 용액은 $25 \mathrm{~mL}$ acetate buffer(300 mM, pH 3.6), 40 $\mathrm{mM} \mathrm{HCl}$ 에 용해한 $10 \mathrm{mM}$ 2,4,6-tris(2-pyridyl)-s-triazine (TPTZ, Sigma-Aldrich Co.) $2.5 \mathrm{~mL}$ 및 $20 \mathrm{mM}$ ferric chloride $\left(\mathrm{FeCl}_{3}\right) 2.5 \mathrm{~mL}$ 를 혼합하여 제조한 후, $37^{\circ} \mathrm{C}$ 에서 10 분간 가온하였다. 시료 $30 \mu \mathrm{L}$ 와 제조된 FRAP 용액 900 $\mu \mathrm{L}$ 및 증류수 $90 \mu \mathrm{L}$ 를 넣은 후 상온에서 30 분간 반응시킨 후 분광광도계(Ultraspec 2100pro, Biochrom Ltd.)를 이용하 여 흡광도 $510 \mathrm{~nm}$ 에서 측정하였다. $\mathrm{FRAP}$ 는 $\mathrm{FeSO}_{4}$. $7 \mathrm{H}_{2} \mathrm{O}$ (Sigma-Aldrich Co.)로 표준곡선을 작성하여 계산하 였다.

폐상피세포주 및 대식세포주 배양

실험에 사용한 인간 폐상피세포주인 L-132 세포 및 대식 세포주인 RAW264.7 세포는 한국세포주은행(KTCC, Seoul, Korea)에서 분양받아 사용하였다. 세포배양은 dulbeco's modifled eagle's media(DMEM) 배지(Welgene, Daegu, Korea)를 이용하여 각각 $10 \%$ fetal bovine serum(Gibco BRL Co., Grand Island, NY, USA), $1 \%$ penicillin-streptomycin (Gibco BRL Co.)을 첨가하여 배양하였다. 세포는 모두 3 $7^{\circ} \mathrm{C}, 5 \% \mathrm{CO}_{2}$ incubactor(MCO-18 AIC, Sanyo Co., Osaka, Japan)에서 배양하였다.

\section{세포독성}

L-132 세포 및 RAW264.7 세포의 세포독성은 methyl thiazol-2-YL-2,5-diphenyl tetrazolium bromide(MTT) assay 로 측정하였으며, 배양된 세포주를 각각 $1 \times 10^{4}$ 및 $5 \times 10^{4}$ cell/well의 농도로 조정하여 96 well plate에 $100 \mu \mathrm{L}$ 씩 첨가 하여 24시간 배양하고 이후 새로운 배지에 시료를 농도별 로 처리한 다음 24 시간 동안 배양하였다. 배양 후 PBS 완충 용액에 녹인 MTT(5 mg/mL, Sigma-Aldrich Co.) 용액을 각 well에 $10 \mu \mathrm{L}$ 씩 첨가하고 다시 4시간 동안 배양하여 MTT가 환원되도록 하였다. 이후 상등액을 완전히 제거하고 dimethyl sulfoxide(DMSO, Junsei Chemical Co., Tokyo, Jpan) $100 \mu \mathrm{L}$ 를 각 well에 첨가하여 10 분간 반응시켜 formazan 결정을 완전히 용해한 다음 microplate reader 
(UVM-340, Asys Co., Biochrom, Cambridge, UK)를 이용하 여 흡광도 $540 \mathrm{~nm}$ 에서 측정하였다.

\section{세포보호 효과}

L-132 세포를 이용한 세포보호 효과는 Hwang(30)의 방 법을 응용하여 측정하였다. 배양된 L-132 세포를 $1 \times 10^{4}$ cell/well의 농도로 조정하여 96 well plate에 $100 \mu \mathrm{L}$ 씩 첨가 하여 24시간 배양하였다. 그 후, 새로운 배지로 교환하고 $\mathrm{H}_{2} \mathrm{O}_{2}$ (Duksan pure chemicals Co., Ltd, Ansan, Korea) $1 \mathrm{mM}$ 및 시료를 농도별로 처리한 다음 6시간 동안 배양하였다. 배양 완료 후, PBS 완충용액에 녹인 $\mathrm{MTT}(5 \mathrm{mg} / \mathrm{mL}$, Sigma-Aldrich Co.) 용액을 각 well에 $10 \mu \mathrm{L}$ 씩 첨가하고 2시간 동안 배양하여 MTT가 환원되도록 하였다. 이후 상등 액을 모두 제거하고 DMSO(Junsei Chemical Co.) $100 \mu \mathrm{L}$ 를 각 well에 첨가하여 10 분간 반응시켜 formazan 결정을 용해 한 다음 microplate reader (UVM-340, Asys Co.)를 이용하여 흡광도 $540 \mathrm{~nm}$ 에서 측정하였다.

\section{Nitric oxide 생성량 측정}

RAW264.7 세포를 $5 \times 10^{4}$ cell/well이 되도록 96 well plate 에 각각 $100 \mu \mathrm{L}$ 씩 첨가하여 24시간 배양하고, 농도별 시료 및 lipopolysaccharide(LPS, $0.1 \mu \mathrm{g} / \mathrm{mL}$, Sigma-Aldrich Co.)를 처리하여 24시간 배양하였다. 배양이 완료된 후 상등액 50 $\mu \mathrm{L}$ 에 동량의 Griess 시약(Sigma-Aldrich Co.)을 혼합하여 10 분간 반응시킨 후 microplate reader(UVM-340, Asys Co.) 를 이용하여 흡광도 $540 \mathrm{~nm}$ 에서 측정하였으며, nitric oxide 생성량은 sodium nitrite(Sigma-Aldrich Co.)의 농도별로 작 성한 표준곡선을 이용하여 계산하였다.

\section{통계처리}

모든 실험결과는 IBM SPSS Statistics(19.0, IBM Corp., Armonk, NY, USA)를 이용한 분산분석(ANOVA)을 실시하 였고 각 측정 평균값의 유의성 $(\mathrm{p}<0.05)$ 은 Duncan's multiple range test를 실시하여 검정하였다.

\section{결과 및 고찰}

추출수율, 총 폴리페놀, 총 플라보노이드 및 총 당 함량 맥문동, 오미자 및 인삼 혼합추출물의 추출수율, 총 폴리 페놀, 총 플라보노이드 및 총 당 함량은 Table 2 와 같다. 혼합비율에 따른 추출수율은 25.33-33.87\%로 나타났고, 맥 문동, 오미자 및 인삼의 혼합비율에 따른 총 폴리페놀 함량 은 0.65-1.01 g/100 g으로, 동의보감 및 일반적으로 많이 이용하고 있는 생맥산 혼합비율을 대조구로 설정한 $\operatorname{MEC}(0.65 \mathrm{~g} / 100 \mathrm{~g})$ 추출물보다 오미자의 혼합비율이 높은 $\operatorname{ME} 1(1.01 \mathrm{~g} / 100 \mathrm{~g})$ 추출물이 더 높게 나타났다. 총 플라보노
이드 함량은 대조구 $\mathrm{MEC}(0.05 \mathrm{~g} / 100 \mathrm{~g})$ 추출물보다 맥문동, 오미자 및 인삼의 혼합비율을 다르게 설정한 실험구 $\mathrm{ME1}$, ME2 및 ME3(0.06-0.07 g/100 g) 추출물에서 높게 나타났으 나, 유의적인 차이는 나타나지 않았다. 오미자는 안토시아 닌, lignan 유도체(schizanrin 및 gomisin 유도체)를 가지며 $(31,32)$, 특히 오미자에서 얻어지는 폴리페놀 화합물은 매 우 높은 항산화능을 가지는 것으로 알려져 있으며, 높은 항산화능은 생체 내 항암 및 면역증진 활성과도 연관이 있다(33).

혼합비율에 따른 총 당 함량은 $21.34-22.83 \mathrm{~g} / 100 \mathrm{~g}$ 으로, 유의적인 차이는 나타나지 않았으나 맥문동의 혼합비율이 높은 $\operatorname{MEC}(22.83 \mathrm{~g} / 100 \mathrm{~g})$ 및 $\operatorname{ME} 3(22.41 \mathrm{~g} / 100 \mathrm{~g})$ 추출물에 서 높게 나타났다. Lee 등(34)의 연구에서 생맥산의 구성 약물 추출물의 총 당 함량을 측정한 결과, 맥문동은 $1,788.34 \mathrm{mg} / 100 \mathrm{~mL}$ 로 가장 높게 나타났으며, 오미자 및 인삼은 각각 $297.17 \mathrm{mg} / 100 \mathrm{~mL}$ 및 $193.93 \mathrm{mg} / 100 \mathrm{~mL}$ 로 나타났다. 이는 맥문동의 혼합비율이 높은 $\mathrm{MEC}$ 및 $\mathrm{ME3}$ 추출물에서 총 당 함량이 높게 나타난 본 연구와 유사하였 다.

Table 2. Yield, total polyphenol, total flavonoid, and total sugar contents of mixture extracts from Liriope platyphylla, Schizandra chinensis, and Panax ginseng C.A. Meyer

\begin{tabular}{ccccc}
\hline Samples $^{1)}$ & $\begin{array}{c}\text { Yield } \\
\text { (dry basis, \%) }\end{array}$ & $\begin{array}{c}\text { Total polyphenol } \\
\text { contents } \\
\text { (Tamin acid, g/100 g) }\end{array}$ & $\begin{array}{c}\text { Total flavonoid } \\
\text { contents } \\
\text { (Rutin, g/100) }\end{array}$ & $\begin{array}{c}\text { Total sugar } \\
\text { contents } \\
\text { (Glucose, g/100 g) }\end{array}$ \\
\hline MEC & $31.13 \pm 0.01^{\mathrm{b} 2)}$ & $0.65 \pm 0.00^{\mathrm{d}}$ & $0.05 \pm 0.00^{\mathrm{b}}$ & $22.83 \pm 0.80^{\mathrm{a}}$ \\
$\mathrm{ME1}$ & $33.87 \pm 0.13^{\mathrm{a}}$ & $1.01 \pm 0.06^{\mathrm{a}}$ & $0.07 \pm 0.01^{\mathrm{a}}$ & $21.36 \pm 1.06^{\mathrm{a}}$ \\
ME2 & $25.33 \pm 0.08^{\mathrm{d}}$ & $0.80 \pm 0.01^{\mathrm{bc}}$ & $0.07 \pm 0.01^{\mathrm{a}}$ & $21.34 \pm 1.29^{\mathrm{a}}$ \\
ME3 & $30.33 \pm 0.13^{\mathrm{c}}$ & $0.85 \pm 0.03^{\mathrm{b}}$ & $0.06 \pm 0.00^{\mathrm{ab}}$ & $22.41 \pm 1.38^{\mathrm{a}}$ \\
\hline
\end{tabular}

${ }^{1)}$ MEC, Mixed extract of control (Liriope platyphylla : Schizandra chinensis : Panax ginseng C.A. Meyer $=2: 1: 1$ ); ME1, Mixed extract 1 (Liriope platyphylla : Schizandra chinensis : Panax ginseng C.A. Meyer $=1: 2: 1)$; ME2, Mixed extract 2 (Liriope platyphylla : Schizandra chinensis : Panax ginseng C.A. Meyer $=1$ : 1 : 2); ME3, Mixed extract 3 (Liriope platyphylla : Schizandra chinensis : Panax ginseng C.A. Meyer $=1.34: 1.33: 1.33$ ).

${ }^{2)}$ Means \pm SD ( $\mathrm{n}=3$ ) with different letters (a-d) above bars are significantly different by Duncan's multiple range test $(\mathrm{p}<0.05)$.

\section{항산화 활성}

맥문동, 오미자 및 인삼의 혼합비율에 따른 DPPH, ABTS 및 Superoxide radical 소거활성은 Fig. 1 및 2와 같다. DPPH 및 ABTS radical 소거활성에서 각각 7.16-26.79\% 및 7.04-21.09\%로 농도가 증가함에 따라 모든 시료에서 소거 활성이 증가하였으며, 양성대조구(ascorbic acid, $50 \mu \mathrm{g} / \mathrm{mL}$ ) 에서는 각각 $45.21 \%$ 및 $45.50 \%$ 로 나타났다. 대조구 $\mathrm{MEC}$ 추출물 $(1,000 \mu \mathrm{g} / \mathrm{mL})$ 에서 각각 $21.46 \%$ 및 $13.07 \%$ 로 나타났 으며, 실험구에서는 오미자의 혼합비율이 높은 $\mathrm{ME1}$ 추출 물 $(1,000 \mathrm{\mu g} / \mathrm{mL})$ 에서 각각 $26.79 \%$ 및 $21.09 \%$ 로 대조구 $\mathrm{MEC}$ 추출물보다 높게 나타났으며, 이는 총 폴리페놀 함량 
과 유사한 경향을 나타내었다. Kang 등(35)은 전자공여능 이 phenolic acid, flavonoids 및 그 외 페놀성 물질에 대한 항산화 활성의 지표라고 하였으며, 식물 내 총 폴리페놀 함량은 전자공여능과 밀접한 관계가 있어 총 폴리페놀 함량 이 높을수록 전자공여능이 높다고 보고하였다(36). 본 연구 에서도 오미자의 혼합비율이 높은 $\mathrm{ME1}$ 추출물에서 총 폴 리페놀 함량과 DPPH 및 $\mathrm{ABTS}$ radical 소거활성이 높게 나타나 유사한 경향을 나타났는데, 이는 $\mathrm{Kim}$ 등(37)의 연구 와 같이 오미자의 성분인 schizandrin, schizandran, $\gamma$ -schizandrin, ethamigrenal, gomisin류 중에서 특히 수종의 gomisin의 항산화 작용에 의한 것으로 사료된다.

(A)

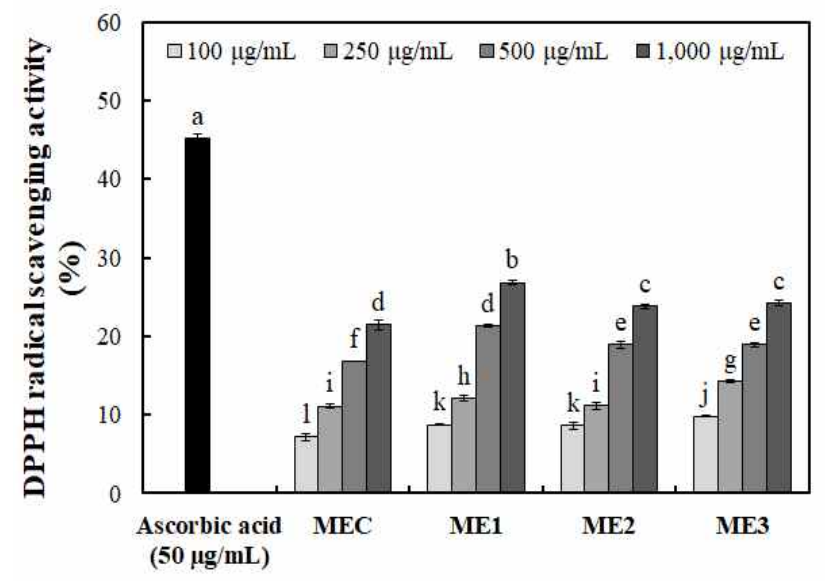

(B)

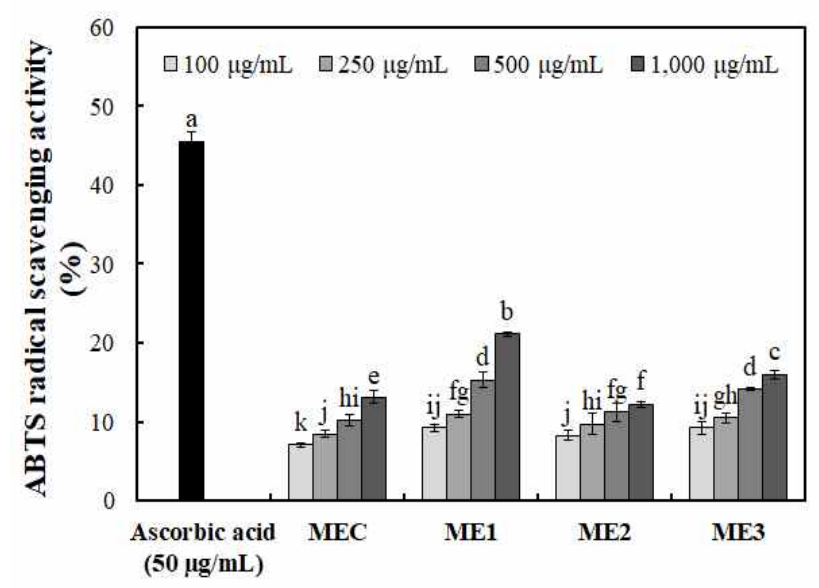

Fig. 1. DPPH (A) and ABTS (B) radical scavenging activity of mixture extracts from Liriope platyphylla, Schizandra chinensis, and Panax ginseng C.A. Meyer.

MEC, Mixed extract of control (Liriope platyphylla : Schizandra chinensis : Panax ginseng C.A. Meyer = 2:1:1); ME1, Mixed extract 1 (Liriope platyphylla $:$ Schizandra chinensis: Panax ginseng C.A. Meyer $=1: 2: 1$ ); ME2, Mixed extract 2 (Liriope platyphylla : Schizandra chinensis: Panax ginseng C.A. Meyer $=1: 1: 2$ ); ME3, Mixed extract 3 (Liriope platyphylla : Schizandra chinensis : Panax ginseng C.A. Meyer $=1.34: 1.33: 1.33$.

Means \pm SD $(n=3)$ with different letters $(\mathrm{a}-1)$ above bars are significantly different by Duncan's multiple range test $(\mathrm{p}<0.05)$.
맥문동, 오미자 및 인삼의 혼합비율에 따른 FRAP 활성은 Fig. 2와 같다. FRAP 활성은 각각 15.95-67.83\% 및 135.63-295.47 $\mu \mathrm{M}$ 로 나타났으며, 농도가 증가함에 따라 모 든 시료에서 소거활성이 증가하였다. Radical 소거활성과 같이 오미자의 혼합비율이 높은 $\mathrm{ME} 1$ 추출물 $(1,000 \mu \mathrm{g} / \mathrm{mL})$ 에서 각각 $67.83 \%$ 및 $295.47 \mu \mathrm{M}$ 로 가장 높게 나타났다. Holasova 등(38)은 페놀화합물의 함량이 높을수록 항산화 활성이 증가한다고 보고한 것과 같이 총 폴리페놀 및 총 플라보노이드 함량에서 가장 높게 나타난 높은 $\mathrm{ME1}$ 추출 물의 항산화 활성이 가장 높게 분석되었다.

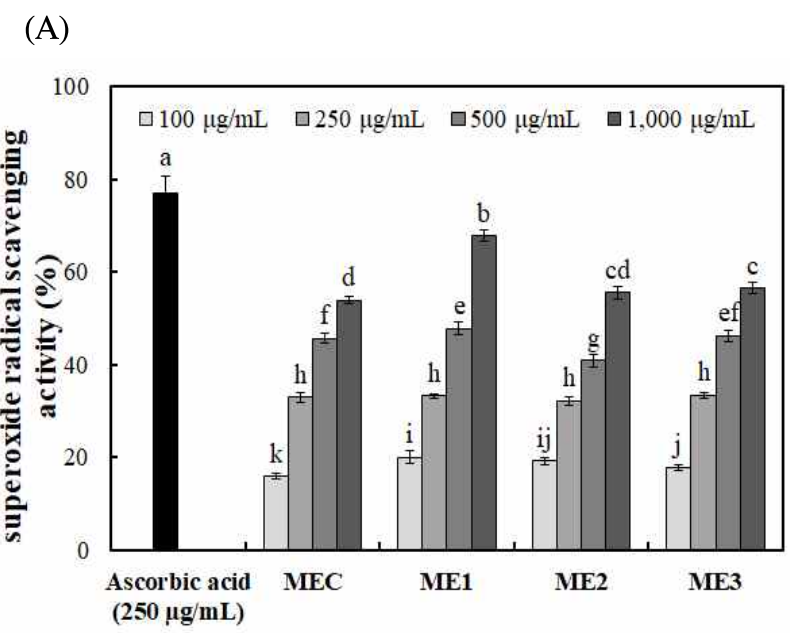

(B)

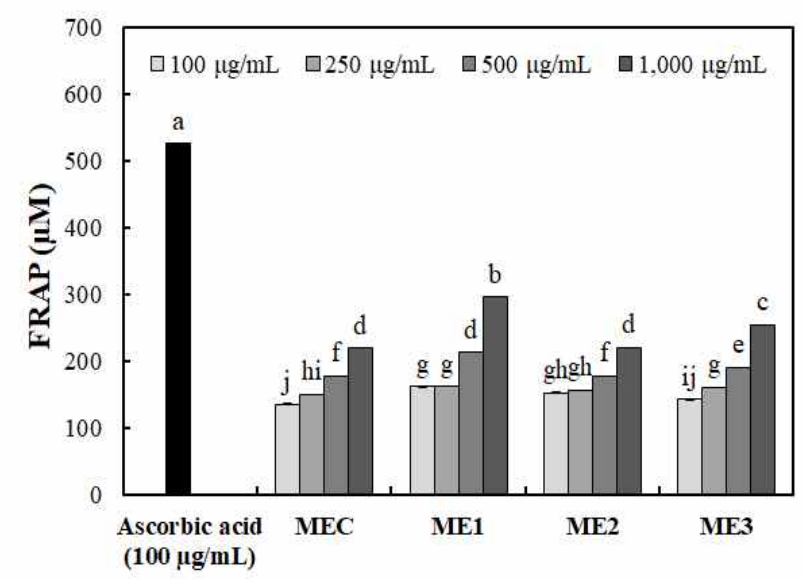

Fig. 2. Superoxide radical scavenging activity (A) and FRAP (ferric reducing antioxidant power) (B) of mixture extracts from Liriope platyphylla, Schizandra chinensis, and Panax ginseng C.A. Meyer.

MEC, Mixed extract of control (Liriope platyphylla : Schizandra chinensis : Panax ginseng C.A. Meyer $=2: 1: 1$ ); ME1, Mixed extract 1 (Liriope platyphylla : Schizandra chinensis : Panax ginseng C.A. Meyer $=1: 2: 1$ ); ME2, Mixed extract 2 (Liriope platyphylla : Schizandra chinensis : Panax ginseng C.A Meyer = $1: 1: 2) ;$ ME3, Mixed extract 3 (Liriope platyphylla : Schizandra chinensis : Panax ginseng C.A. Meyer $=1.34: 1.33: 1.33)$.

Means \pm SD ( $\mathrm{n}=3$ ) with different letters $(\mathrm{a}-\mathrm{k})$ above bars are significantly different by Duncan's multiple range test $(\mathrm{p}<0.05)$. 


\section{세포보호 효과}

맥문동, 오미자 및 인삼 혼합추출물 $(100-2,500 \mu \mathrm{g} / \mathrm{mL})$ 을 처리하였을 때 모든 시료에서 $90 \%$ 이상의 세포 생존율이 나타나 세포독성이 없음을 확인하였고, $100-1,000 \mu \mathrm{g} / \mathrm{mL}$ 농도로 하여 L-132 세포의 세포보호 효과를 실험한 결과는 Fig. 3과 같다.

본 실험에서 사용한 $\mathrm{H}_{2} \mathrm{O}_{2}$ 는 산화적 스트레스를 유발하 는 물질로 원형질막 통과가 쉽기 때문에 in vitro 및 in vivo 실험에서 산화적 손상을 주는 독성 물질로 많이 이용되고 있다(39). $\mathrm{H}_{2} \mathrm{O}_{2}$ 에 의한 L-132 세포 생존율은 $51.43 \%$ 로 나타 났으며, 산화적 손상에 대한 세포보호 효과는 $1,000 \mu \mathrm{gg} / \mathrm{mL}$

(A)

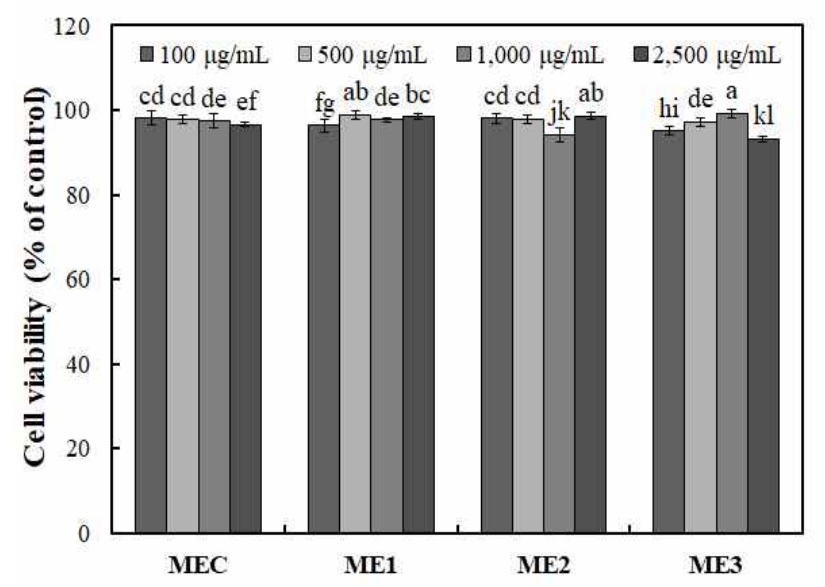

(B)

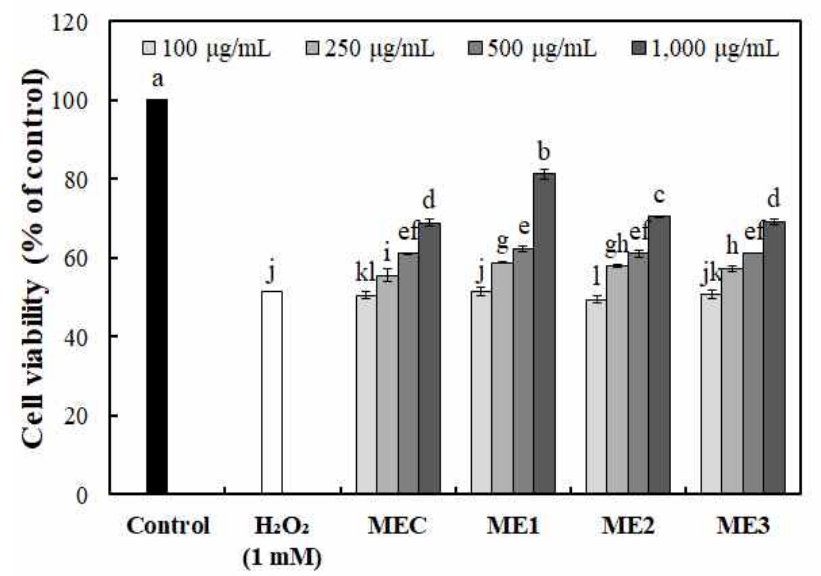

Fig. 3. MTT assay (A) and protective effects on cell viability against $\mathrm{H}_{2} \mathrm{O}_{2}(1 \mathrm{mM})$ induced oxidative damage in (B) in L-132 cell line of mixture extracts from Liriope platyphylla, Schizandra chinensis, and Panax ginseng C.A. Meyer.

MEC, Mixed extract of control (Liriope platyphylla : Schizandra chinensis : Panax ginseng C.A. Meyer $=2: 1: 1)$; ME1, Mixed extract 1 (Liriope platyphylla : Schizandra chinensis : Panax ginseng C.A. Meyer $=1: 2: 1$ ); ME2, Mixed extract 2 (Liriope platyphylla : Schizandra chinensis: Panax ginseng C.A. Meyer $=1: 1: 2) ; \mathrm{ME}$, Mixed extract 3 (Liriope platyphylla : Schizandra chinensis : Panax ginseng C.A. Meyer $=1.34: 1.33: 1.33$.

Means \pm SD $(n=3)$ with different letters $(a-1)$ above bars are significantly different by Duncan's multiple range test $(\mathrm{p}<0.05)$.
농도에서 68.89-81.22\%로, 대조구 $\mathrm{MEC}$ 추출물에서 $68.89 \%$ 로 가장 낮은 생존율을 나타냈으며, 실험구 추출물 은 모두 대조구보다 높은 생존율을 나타내었다. 그 중에서 오미자의 혼합비율이 높은 $\mathrm{ME} 1$ 추출물 $(1,000 \mu \mathrm{g} / \mathrm{mL})$ 에서 $81.22 \%$ 로 가장 높은 세포보호 효과를 나타내었는데 이는 총 폴리페놀 함량이 가장 많이 함유되어 있는 오미자의 혼합비율이 높은 $\mathrm{ME1}$ 추출물의 폴리페놀 성분이 세포내 산화적 손상에서 세포보호 효과를 보인 것으로 사료된다. Chung 등(40)의 연구에서 추출 용매에 따른 아마란스 종자 추출물의 L-132 세포보호 효과를 실험한 결과 폴리페놀과 탄닌의 함량이 높은 물 추출물에서 $\mathrm{H}_{2} \mathrm{O}_{2}$ 세포내 보호활성 도가 높게 나타나 본 연구와 유사한 경향을 나타내어 폴리

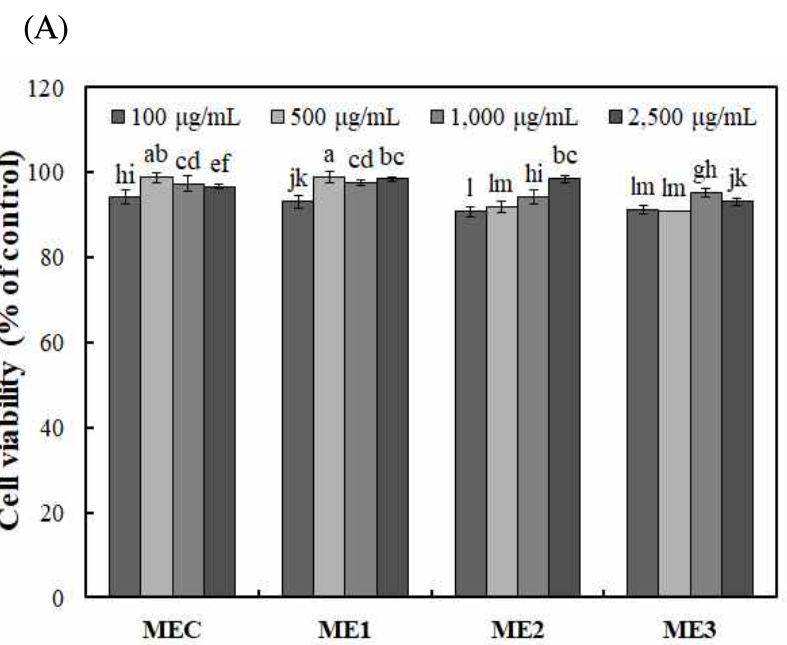

(B)

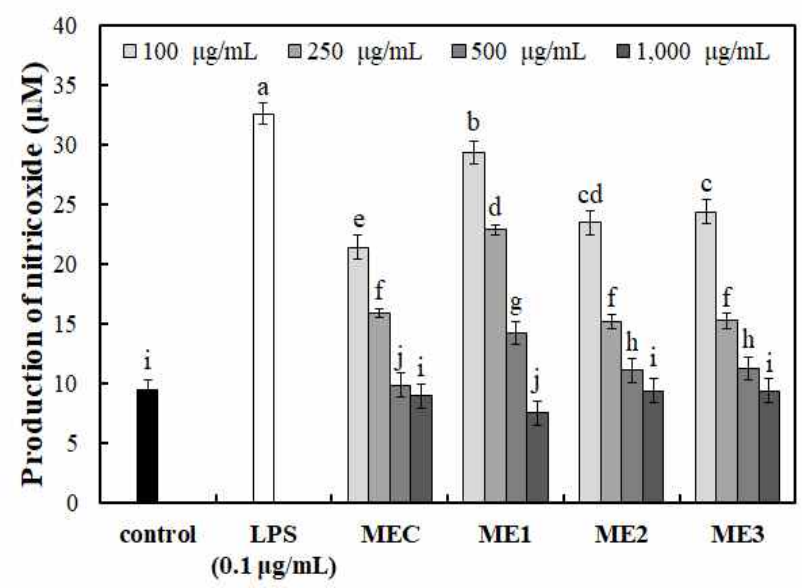

Fig. 4. MTT assay (A) and nitric oxide production (B) in RAW264.7 cell line of mixture extracts from Liriope platyphylla, Schizandra chinensis, and Panax ginseng C.A. Meyer.

MEC, Mixed extract of control (Liriope platyphylla : Schizandra chinensis : Panax ginseng C.A. Meyer = 2:1:1); ME1, Mixed extract 1 (Liriope platyphylla: Schizandra chinensis: Panax ginseng C.A. Meyer $=1: 2: 1$ ); ME2, Mixed extract 2 (Liriope platyphylla : Schizandra chinensis : Panax ginseng C.A. Meyer $=1: 1: 2) ; \mathrm{ME} 3$, Mixed extract 3 (Liriope platyphylla : Schizandra chinensis : Panax ginseng C.A. Meyer $=1.34: 1.33: 1.33)$.

Means \pm SD ( $n=3)$ with different letters $(a-m)$ above bars are significantly different by Duncan's multiple range test $(\mathrm{p}<0.05)$. 
페놀 성분이 세포보호 효과가 있음을 확인하였다.

Nitric oxide 생성 억제능

맥문동, 오미자 및 인삼 혼합추출물 $(100-10,000 \mu \mathrm{g} / \mathrm{mL})$ 을 처리하였을 때 모든 시료에서 $90 \%$ 이상의 세포 생존율 이 나타나 세포독성이 없음을 확인하고, $100-1,000 \mu \mathrm{g} / \mathrm{mL}$ 농도로하여 RAW264.7 세포의 nitric oxide 생성 억제능을 확인한 결과는 Fig. 4 와 같다.

활성산소 중 하나이며, 최근 염증 유발에 중요한 역할을 하는 것으로 알려진 nitric oxide 생성에 대한 맥문동, 오미자 및 인삼 혼합추출물의 효과를 측정한 결과, nitric oxide 생성 량은 $\mathrm{LPS}(0.1 \mu \mathrm{g} / \mathrm{mL})$ 처리구에서 $32.56 \mu \mathrm{M}$ 로 나타났으며, 모든 시료에서 농도 의존적으로 nitric oxide 생성량이 감소 하였다. $1,000 \mu \mathrm{g} / \mathrm{mL}$ 농도에서 대조구 MEC 추출물은 8.92 $\mu \mathrm{M}$ 의 nitiric oxide 생성량을 나타내었으며, 실험구에서는 인삼의 혼합비율이 높은 ME2 추출물이 $7.48 \mu \mathrm{M}$ 로 대조구 보다 낮은 nitric oxide 생성량을 나타내었다. 홍삼으로부터 분리된 산성 다당체의 대식세포로부터 iNOS 발현 및 NO 생성에 의한 면역 조절작용과 산성 다당체의 신호전달 활성 화를 통한 대식세포 활성화 등 많은 연구결과가 보고되어 있어(41,42), 이 연구결과와 같이 면역체계에 기여한다고 알려져 있는 다당체가 $60-70 \%$ 이루어진 인삼이 모든 시료 에 혼합되어 있어 시료 간의 유의적인 차이가 나지 않는 것으로 사료된다. 그러나 인삼의 혼합비율이 높은 $\mathrm{ME2}$ 추 출물에서 NO 생성량이 가장 적게 나타나 앞선 연구와 유사 한 경향을 나타내었다.

\section{요 약}

생맥산 원료인 맥문동, 오미자 및 인삼의 최적 혼합비율 을 설정하고자 맥문동, 오미자 및 인삼 혼합추출물을 제조 하여 이화학적 특성 및 생리활성을 조사하였다. 맥문동, 오미자 및 인삼 혼합추출물의 추출수율은 $25.33-33.87 \%$ 이 었으며, 총 폴리페놀 및 총 플라보노이드 함량은 오미자의 혼합비율이 높은 추출물(ME1)에서 각각 $1.01 \mathrm{~g} / 100 \mathrm{~g}$ 및 $0.07 \mathrm{~g} / 100 \mathrm{~g}$ 으로 가장 높은 값을 나타내었고, 총 당 함량은 맥문동의 혼합비율이 높은 추출물(MEC)에서 $22.83 \mathrm{~g} / 100$ $\mathrm{g}$ 으로 가장 높은 값을 나타내었다. DPPH radical 및 ABTS radical 소거활성은 $\mathrm{ME} 1$ 추출물에서 각각 $26.79 \%$ 및 $21.09 \%$ 로 가장 우수한 radical 소거활성을 나타내었으며, superoxide radical 소거활성 및 FRAP 활성 또한 ME1 추출 물에서 각각 $67.83 \%$ 및 $295.47 \mu \mathrm{M}$ 로 가장 우수한 항산화 활성을 나타내었다. 맥문동, 오미자 및 인삼 혼합추출물의 생리활성을 확인한 결과, $\mathrm{H}_{2} \mathrm{O}_{2}$ 에 의해 산화적 손상된 폐상 피세포인 L-132 세포의 생존율은 51.43\%를 나타낸 반면 $\mathrm{ME} 1$ 추출물 $(1,000 \mu \mathrm{g} / \mathrm{mL})$ 은 $81.22 \%$ 로 가장 높은 세포보호
효과를 나타내었다. LPS로 자극을 유도한 대식세포주인 RAW264.7 세포는 인삼의 혼합비율이 높은 ME2 추출물 $(1,000 \mu \mathrm{g} / \mathrm{mL})$ 은 $7.48 \mu \mathrm{M}$ 로 가장 적은 nitric oxide 생성량을 나타내어 nitric oxide 생성을 억제하였다. 따라서 본 연구에 서는 동의보감 및 일반적으로 많이 이용하고 있는 MEC 추출물보다 ME1 및 ME2 추출물에서 항산화 활성 및 면역 조절능이 우수함을 확인하여, 새로운 생맥산 혼합비율을 이용한 항산화 활성 및 면역조절용 기능성 식품 소재 개발 이 가능할 것으로 사료된다.

\section{References}

1. Rim YS, park YM, Park MS, Kim KY, Kim MJ, Choi YH (2000) Screening of antioxidants and antimicrobial activity in native plants. Korean J Med Crop Sci, 8, 342-350

2. Ju JC, Shin JH, Lee SJ, Cho HS, Sung NJ (20060 Antioxidative activity of hot water extracts from medicinal plants. J Korean Soc Food Sci Nutr, 35, 7-14.

3. Yu AR, Park HY, Choi IW, Park YK, Hong HD, Choi HD (2012) Immune enhancing effect of medicinal herb extracts on a RAW264.7 macrophage cell line. J Korean Soc Food Sci Nutr, 41, 1521-1527

4. Lee HJ, Kim NY, Jang MK, Son HJ, Kim KM, Sohn DH, Lee SH, Ryu JH (1999) A sesquiterpene, dehydrocostus lactone, inhibits the expression of inducible nitric oxide synthase and TNF-a in LPS-activated macrophages. Planta Med, 65, 104-108

5. deRojas-Walker T, Tamir S, Ji H, Wishnok JS, Tannenbaum SR (1995) Nitric oxide induces oxidative damage in addition to deamination in macrophage DNA. Chem Res Toxicol, 8, 473-477

6. Akira S, Takeda K (2004) Toll-like receptor signaling. Nature reviews immunology, 4, 499-511

7. Ames BN, Shigenaga MK, Hagen TM (1993) Oxidants, antioxidants, and the degenerative diseases of aging. Proc Natl Acad Sci USA, 90, 7915-7922

8. Kim JS, Choi SY (2008) Physicochemical properties and antioxidative activities of Omija(Schizandra chinensis Bailon). Korean J Food Nutr, 21, 35-42

9. Hur NY, Baek EK (2005) Development of traditional drinks using Sangmaksan. Korean J Culinary Res, 11, 166-178

10. Kim JH, Kim JE, Lee YK, Nam SH, Her YK, Jee SW, Kim SG, Park DJ, Choi YW, Hwang DY (2010) The extracts from Liriope platyphylla significantly stimulated insulin secretion in the HIT-T15 pancreatic $\beta$-cell line. 
J Life Sci, 20, 1027-1033

11. Cho HJ, Hyun BK, Soun YK, Park CW, Chun HC, Song KC, Noh DC, Yun KH (2013) A Study on soil suitability criteria for Liriopis platyphylla. Korean J Soil Sci Fert, 46, 542-548

12. Tomoda M, Kato S (1968) Water soluble carbohydrates of Ophiopogon tuber. П, Purification, properties and structures of three oligosaccharides. Chem Pharm Bull, 16, 113-116

13. Lee DY, Son KH, Do JC, Kang SS (1989) The new steroidal saponins from the tuber of Lirope spocata. Arch Pharm Res, 12, 295-299

14. Park JH, Kim JH, Kim DH, Mun HC, Lee HJ, Seo SM, Paik KH, Ryu LH, Park JI, Lee HY (2004) Comparison of immuno-stimulatory activities by purification process of Schizandra chinensis baillon fruits. Korean J Medicinal Crop Sci, 12, 141-148

15. Sung KC (2011) A study on the pharmaceutical \& chemical characteristics and analysis of natural Omija extract. J of the Korean Oil Chemists' Soc, 28, 290-298

16. Kim CJ, Suh HJ (2005) Antioxidant activities of Rhubarb extracts containing phenolic compounds. Korean J Food Culture, 20, 77-85

17. Chung YS, Chang YH, Sung JH (2006) The effect of ginseng and caffeine products on the antioxidative activities of mouse kidney. J Cinseng Res, 30, 15-21

18. Sanada S, Kondo N, Shoji J, Tanaka O, Shibata S (1974) Studies on the saponins of ginseng. I. structure of ginsenoside- $\mathrm{R}_{0},-\mathrm{Rb}_{1},-\mathrm{Rb}_{2}, \mathrm{Rc}$ and $\mathrm{Rd}$. Chem Pharm Bull, 22, 421-428

19. Park JD (1996) Recent studies on the chemical constituents of Korean ginseng(Panax ginseng C.A. Meyer). Korean J Ginseng Sci, 20, 389-415

20. Park CK, Jeon BS, Yang JW (2003) The chemical components of Korean ginseng. Food Industry and Nutrition, 8, 10-23

21. Benishin CG, Lee R, Wang LC, Liu HJ (1991) Effects of ginsenoside on central cholinergic metabolism. Pharmacology, 42, 223-229

22. Kim SS, Park HY, Byun YH, Hwang BG, Lee JH, Shim YJ, Park CK, Park HM, Yang JW (2002) The effects on the blood lipid profiles and body fat by long term administration of red ginseng product. J Ginseng Res, 26, 67-73

23. Singleton VL, Rossi JA (1965) Colorimetry of total phenolics with phosphomolybdic-phosphotungstic acid reagents. AM J Enol Vitic, 16, 144-158

24. Jia Z, Tang M, Wu J (1999) The determination of flavonoid contents in mulberry and their scavenging effects on superoxide radicals. Food Chem, 64, 555-559

25. Dubois M, Gilles KA, Hamilton JK, Rebers PA, Smith F (1956) Colorimetric method for determination of sugars and related substances. J Anal Chem, 28, 350-356

26. Blois MS (1958) Antioxidant determinations by the use of a stable free radical. Nature, 181, 1199-1200

27. Re R, Pellegrini N, Proteggente A, Pannala A, Yang M, Rice-Evans C (1999) Antioxidant activity applying an improved ABTS radical cation decolorization assay. Free Radic Biol Med, 26, 1231-1237

28. Benzie IF, Strain JJ (1996) The ferric reducing ability of plasma (FRAP) as a measure of "antioxidant power" the FRAP assay. Anal Biochem, 239, 70-76

29. Oyaizu M (1986) Studies on products of browning reaction-antioxidative activities of products of browning reaction prepared from glucosamine. Jpn J Nutr, 44, 307-315

30. Hwang EG (2003) Protective effects of a-tocopherol and captopril against hydrogen peroxide-induced apoptosis on human lug epithelial cell line L-132. Ph D Thesis, Kyunghee University, Korea, p 32

31. Ohtaki Y, Hida T, Hiramatsu K, Kanitani M, Ohshima T, Nomura M, Wakita H, Aburada M, Miyamoto KI (1996) Deoxycholic acid as an endogenous risk factor for hepatocarcinogenesis and effects of gomisin A, a lignan component of Schizandra fruits. Anticancer Res, 16, 751-755

32. Cho YJ, Ju IS, Chun SS, An BJ, Kim JH, Kim MU, Kwon OJ (2008) Screening of biological activities of extracts from Rhododendron mucronulatum Turcz. flowers. J Korean Soc Food Sci Nutr, 37, 276-281

33. Lee YS (2007) Antioxidative and physiological activity of extracts of Angelica dahurica leaves. Korean J Food Preserv, 14, 78-86

34. Lee SH, Park CS, Kim DJ, Kim SM (2009) An analysis of Saengmaegsan's ingredients and a comparison study on anti-oxidation eggects according ti kinds of extract. J Korean Oriental Med, 30, 26-41

35. Kang YH, Park YK, Lee GD (1996) The nitrite scavenging and electron donating ability of phenolic compounds. Korean J Food Sci Technol, 28, 232-239

36. Kim HK, Choi YJ, Kim KH (2002) Functional activities of microwave assisted extracts from Flammulina velutipes. Korean J Food Sci Technol, 34, 1013-1017

37. Kim OC, Jang HJ (1994) Volatile components of Schizandra chinensis Baillon. Korean J Agric Biotech, 39, 279-281

38. Holasova M, Fiedlerova V, Smrcinova H, Orsak M, Lachman J, Vavreinova S (2002) Buckwheat the source 
of antioxidant activity in functional foods. Food Res Int, 35, 207-211

39. Kim MJ, Choi JH, Kwon SH, Kim HD, Bang MH, Yang SA (2013) Characteristics of fermented dropwort extract and vinegar using fermented dropwort extract and its protective effects on oxidative damage in rat glioma C6 cells. Korean J Food Sci Technol, 45, 350-355

40. Chung KH, Jo HJ, Yoon JA, Song BC, An JH (2014) Free radical scavenging activities of amaranth (Amaranthus spp. L) seed extracts. Food Eng Prog, 18, 116-123
41. Chu S, GU J, Feng L, Liu J, Zhang M, Jia X, Liu M, Yao D (2014) Ginsenoside RG5 improves cognitive dysfunction and beta-amyloid deposition in STZ-induced memory impaired rats via attenuating neuroinflammatory responses. Int Immunophermacol, 19, 317-326

42. Lee SE, Park YS (2014) Korean red ginseng water extract inhibits COX-2 expression by suppressing p38 in acrolein treated human endothelial cells. J Ginseng Res, 38, 34-39 